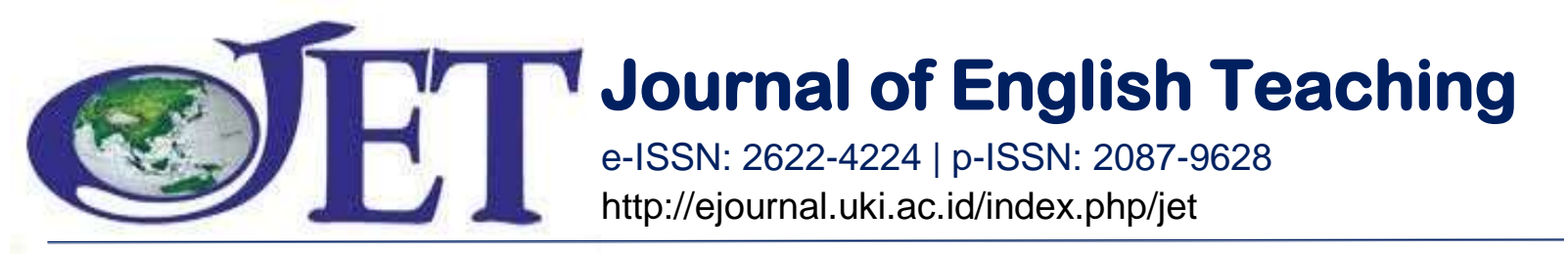

\title{
Students' Perception of Using Group Work in English Class
}

\section{Monica Amelia Situmorang}

Universitas Kristen Indonesia, Jakarta

moamelia25@gmail.com

\begin{abstract}
Group work has become an essential part of modern methodology in teaching and learning because it offers teachers a powerful way to engage students and provides students with opportunities for cooperative learning. This study aimed to find out the students' perception of using group work in English classes. Employing a survey design involving 50 tenth and eleventh graders, it was conducted in SMA 17 Agustus 1945 Jakarta. Data were collected through a questionnaire including five indicators. The collected data were analyzed using the descriptive technique. Findings revealed that group work had a positive impact on students' attitudes. Moreover, group work enlarged their commitment in completing assignments.
\end{abstract}

Keywords:

group work, students' perception, senior high school

\section{How to cite:}

Situmorang, M.A. (2021). Students' Perception of Using Group Work in English Class. Journal of English teaching, 7(1), 81-88. DOI: https://doi.org/10.33541/jet.v7i1.2302

\section{INTRODUCTION}

Humans are social creatures. It means that the main aspects of human beings are to learn to grow up and participate in society or work in groups. Work in a group aims to strengthen human capacities which include the capability to overcome frustration healthily and optimistically, to cooperate, to make decisions, and to achieve kinds of value individually through group participation (Dhawan, 2015).

Nowadays schools and academic institutions mostly use group work as the method in teaching. The idea of work in groups wherein students commonly work together, engaging in discussion, and helping one another in understanding the lesson is not something new (Meng, 2009). In the EFL classroom, most teachers are accustomed to applying a group work method as cooperative learning in teaching especially in task and 
discussion activities. Students have to work together for the completion of the task or assignment to acquire knowledge, competence, and cooperative teamwork capability.

Group work or cooperative learning has become a part and partial of modern methodology in teaching and learning. Group work is typically viewed as a comprehensive umbrella idea for various modes in teaching, whereas collaboration is more of a particular idea that may be included in the much wider concept of cooperation (Chiriac, 2014). Group work offers the teachers a powerful way to engage students, to increase the quality and challenge of the task that students had experienced, giving students chances for cooperative learning, and minimize valuation loads (Gibbs in Bentley \& Warwick, (2017)). Group work requires the responsibility of every person in a group. If one does not work well, the group's failure may occur.

Based on my experience in teaching practiced at senior high school, I noticed most of the teachers used the group work method in a learning activity. Some students were happy working in a group, and also half of them were not fascinated to work with their friends in a group. Thus, there were different perceptions of students through the use of group work in class.

Various studies have been conducted on group work in the classrooms. Most revealed a positive viewpoint of the group work method at some overseas education. However, different results may occur in different countries, dependent on the environment and how the group work method is implemented by the teacher. Teachers have to understand steps in implementing group work, so students will develop their social interaction by helping each other to be better in doing a task cooperatively. Daba, Ejersa, and Aliyi (2016) conducted a study of second-year biology students of Bule Hora University. They found that the students' perception of the benefits of group assignment is positive since their learners prefer to do assignments in a group rather than individual assignment and classroom tests. Kondo's (2010), study involving second-year students of the Kosen revealed that students had positive attitudes of group works activities over individual activities. Taqi and Al Nouh (2014) reported that students who worked in groups enjoyed group tasks and preferred to work in a group more often. Kwon's (2014) classroom action research in a university in Thailand showed that most students perceived group work positively, but the met some challenges, especially difficulty in decisionmaking processes and relationships with peers, in the group works. Based on the findings, when implementing and adapting group work technique, teachers are suggested to listen to the student's voice and address their concerns.

Regarding the background above and since studies on group work implementation in EFL classroom in Indonesian context, particularly in secondary school levels, this study was conducted to examine the 17 Agustus senior high school students' perceptions of using group work in English class. It was directed to answer the following question: What is students' perception of group work implementation in their English classroom in SMA 17 Agustus 1945 Jakarta?

\section{LITERATURE REVIEW}

\section{Group Work}

Group work is defined as more than one person working together to complete a task or assignment. The goal of group work is to get students to interact with each other and collaborate to complete a task or assignment. According to Ward and Masgoret (in Daba, Ejersa, \& Aliyi, 2016), group learning which is often used interchangeably with collaborative learning, cooperative learning, peer learning, community learning, and 
constructive learning, has become a common practice in schools and other educational institutions.

Yanse (2016) stated that group work is an effective technique to increase student engagement in order to improve their English speaking skills. Speaking can be understood and mastered if students feel the situation as if they are in the real condition where the language they learned is used. For example, teachers use role-play (group work) as the technique in teaching speaking to give the learners the real experience of the English environment. Risharyani (2010) said teaching reading for the students in senior high school needs appropriate technique so that the students are active and creative in reading lessons. Pardede (2020) showed that group work is one of the effective technique to integrate the 4Cs into EFL integrated skills learning. Working together in groups also allowed students to learn from and teach each other. Group Work could save some preparation time. Tynjala (2012) said that writing is an active process through which writers can explore and make their ideas clear to themselves. Students who do writing, will produce some elements such as vocabulary, grammar, organization, spelling, and punctuation. Some teachers are usually used methods guided writing and individual writing in the class. Whereas in individual writing, students have to write paragraphs individually, they work alone in their task. This method rarely increases students' writing ability, because of the problem of feeling strange and gets some difficulties with English lessons especially in developing paragraphs. Additionally, Reid (in Rochmawati, 2007) said that writing will be easier, better, and more successful when students do talking, drafting, revising, and editing together in the groups that are part of the writing process.

\section{Advantages and Disadvantages in Using Group Work in Classroom}

Group work is used as a tool for learning at all levels in educational systems. Badache in Taqi \& Al-Nouh, (2014) said that group work as an instruction method where learners of different levels combine into small groups and work together towards a specific objective. Albaqshi (2016), stated there are some advantages of using group work i.e: (1) Provide more opportunities to participate in the case of large classes, (2) Foster learners' responsibilities and autonomy, (3) Provide a feeling of contribution, which motivates students to be involved more, and 4) Provide mutual learning and student to student interaction. Additionally, Pardede (2019) posited that group work is an effective technique to facilitate integrative language skills development.

Although working in groups may positively give some effect, there are also times when problems may occur. For example, when one person in a group member dominates the group, the performance reflects the groups' member level instead of the whole group together. Taqi and Al-Nouh (2014), stated there are some disadvantages of group work i.e: 1) Some students get praise for doing very little work while others do most of the work, 2) Some students in a group may work with their friends and leave others. It brings the difficulty of grading every group member, 3) Some students work more than others. Different habits of the students will make some students may do not like to take orders from other students in the group. Some group members may refuse to work with others, and 4) Noise is one of the outstanding disadvantages that discourage many teachers from using group work.

\section{Steps in Implementing Group Work}

The implementation of the group work method in teaching and learning activity is believable to developing social interaction among students. Ellis and Holmes (2017) 
stated there are five steps in implementing group work i.e: 1) Preparing for group work, 2) Designing the group activity, 3) Introducing the group activity, 4) Monitoring the group task, and 5) Ending the group task.

Various researches have been conducted by some researchers. Daba, Ejersa, and Aliyi (2016) researched second-year biology students' Bule Hora University, found that the students' perception about benefits of group assignment is positive since their learners prefer to do assignment in a group rather than individual assignment and classroom tests. However, because the majority of teachers participated in the discussion their students have misconceptions about the objectives of group work, and they reasoned out this by claiming that students perceive group work as a way of getting pass marks than seeing it as a tool of learning cooperatively through activity. The second research was done by Kondo (2010). The study was conducted toward the second-year students of the Kosen. He concluded that the group work method indicates students' positive attitudes over individual activity. He also asserted the advantages such as helping each other, reducing the individual workload, encouraging low-level students to participate in the activity. The other study was conducted by Ning (2013) at a university in the north of China. The result of this study said that the effectiveness of the cooperative learning approach was more than the traditional instruction in improving students' social skills.

\section{METHOD}

This study employed a cross-sectional survey method design. It was conducted to explore the perceptions of senior high school students of group work methods when it is implemented in English class. The population of this research was students of SMA 17 Agustus 1945. Sample was chosen purposively by taking 50 and eleventh tenth graders as the subjects. They were selected because they been quite often used group work in their English classrooms.

To collect data, a questionnaire design using the Likert Scale format was employed. It was adapted from Daba, Ejersa, and Aliyi (2016). Some modifications were made to meet the research conditions. SPSS version 16 was employed to test the questionnaire's validity and reliability using Pearson's Bivariate Correlation test. The result showed that Cronbach's Alpha Reliability value for 21 items wass .810. Thus, it could be concluded that the instrument was reliable.

Due to COVID-19 pandemics, the survey was conducted online. The total statements in the questionnaire was 30 items. The items should be responded by choosing one of five options provided i.e.: strongly disagree, disagree, neutral, agree, and strongly agree. The score range was from 1 (strongly disagree) to 5 (strongly agree). The questionnaire was responded online by the respondents. The collected data were analyzed using the descriptive analysis technique. The data was presented in the form of tables and explained descriptively.

\section{FINDINGS AND DISCUSSION}

\section{Students' Perception of the Advantages of Using Group Work}

As shown in Table 1, the majority of the participants perceived group work use in learning was advantageous. More than three-fourth (79.67\%) of them strongly agreed and agreed that group work gives some advantages in developing their positive attitudes. Only $20 \%$ of them was neutral, $0.33 \%$ disagreed. The mean scores indicated that the participants believed group work is most advantageous to solve problem collaboratively and to teach them to take responsibility. 
Table 1. The Advantages of Group Work

\begin{tabular}{|c|c|c|c|c|c|c|c|}
\hline NO. & Statements & $\begin{array}{l}S D \\
F(\%)\end{array}$ & $\begin{array}{ll}\mathrm{D} \\
\mathrm{F}(\%)\end{array}$ & $\begin{array}{ll}\mathrm{N} \\
\mathrm{F}(\%)\end{array}$ & $\begin{array}{ll}A \\
F(\%)\end{array}$ & $\begin{array}{ll}\mathrm{SA} \\
\mathrm{F}(\%)\end{array}$ & Mean \\
\hline 1. & $\begin{array}{l}\text { Group work taught me to take } \\
\text { responsibility. }\end{array}$ & $0(0)$ & $0(0)$ & $6(12)$ & $33(66)$ & $11(22)$ & 4.1 \\
\hline 2. & $\begin{array}{l}\text { Group work taught to me manage tasks } \\
\text { effectively. }\end{array}$ & $0(0)$ & $0(0)$ & $15(30)$ & 27 (54) & $8(16)$ & 3.86 \\
\hline 3. & $\begin{array}{l}\text { Group work taught me to negotiate with } \\
\text { other group members. }\end{array}$ & $0(0)$ & 1 (2) & $10(20)$ & 31 (62) & $8(16)$ & 3.92 \\
\hline 4. & $\begin{array}{l}\text { Group work taught me to respect the } \\
\text { feelings, opinions, and ideas of others. }\end{array}$ & $0(0)$ & $0(0)$ & $8(16)$ & 27 (54) & $15(30)$ & 3.54 \\
\hline 5. & $\begin{array}{l}\text { Group work taught me to work with other } \\
\text { students who are different. }\end{array}$ & $0(0)$ & $0(0)$ & $15(30)$ & 27 (54) & $8(16)$ & 3.86 \\
\hline 6. & $\begin{array}{l}\text { Group work taught me to solve problems } \\
\text { together. }\end{array}$ & $0(0)$ & $0(0)$ & $6(12)$ & $23(46)$ & $21(42)$ & 4.3 \\
\hline & $\sum f$ & 0 & 1 & 60 & 168 & 71 & T: 300 \\
\hline & $\sum \%$ & 0 & 0.33 & 20 & 56 & 23.67 & $\mathrm{~T}: 100$ \\
\hline
\end{tabular}

\section{Students' Perception of The Effectiveness of Group Work}

The findings showed that there 55.5\% of the students strongly agreed and agreed that the group works offer an effective way of completing the tasks. Meanwhile, $33 \%$ of the students choose neutral, and $11.5 \%$ of them disagreed and strongly disagreed about it (Table 2). The mean scores indicated that the participants believed group work is most effective for finishing assignments. Working together made assignments easier to handle.

Table 2. The Effectiveness of Group Work

\begin{tabular}{|c|c|c|c|c|c|c|c|}
\hline NO. & Statements & $\begin{array}{c}\text { SD } \\
\mathrm{F}(\%)\end{array}$ & $\begin{array}{c}\text { D } \\
\mathrm{F}(\%)\end{array}$ & $\frac{\mathbf{N}}{\mathrm{F}(\%)}$ & $\frac{\text { A }}{F(\%)}$ & $\begin{array}{c}\text { SA } \\
\mathrm{F}(\%)\end{array}$ & Mean \\
\hline 1. & $\begin{array}{l}\text { The assignment becomes easier when } \\
\text { I work with other students. }\end{array}$ & $0(0)$ & $1(2)$ & $18(36)$ & $\begin{array}{l}24 \\
(48)\end{array}$ & $7(14)$ & 3.74 \\
\hline 2. & $\begin{array}{l}\text { The assignment takes a shorten time to } \\
\text { finish when I work with other students. }\end{array}$ & $0(0)$ & $5(10)$ & $11(22)$ & $\begin{array}{l}29 \\
(58)\end{array}$ & $5(10)$ & 3.68 \\
\hline 3 & $\begin{array}{l}\text { It is easy to share work among the } \\
\text { members equally. }\end{array}$ & $3(6)$ & $8(16)$ & $25(50)$ & $\begin{array}{l}12 \\
(24)\end{array}$ & 2 (4) & 3.04 \\
\hline 4. & Group grade is fair. & $2(4)$ & $4(8)$ & $12(24)$ & $\begin{array}{l}24 \\
(48)\end{array}$ & $8(16)$ & 3.64 \\
\hline & $\sum f$ & 5 & 18 & 66 & 89 & 22 & T: 200 \\
\hline & $\sum \%$ & 2.5 & 9 & 33 & 44.5 & 11 & $\mathrm{~T}: 100$ \\
\hline
\end{tabular}

\section{Students' Perception of Teachers' Implementation of Group Work in Teaching}

As shown in Table 3, the students thought their English teacher implemented group work quite often, as $61.34 \%$ of them strongly agreed and agreed that they always used group work activities in and outside of the classroom. They believed group works provided them opportunities to share ideas with their peers. 
Table 3. Teachers' Implementation of Group Work in Teaching

\begin{tabular}{|c|c|c|c|c|c|c|c|}
\hline NO. & Statements & $\begin{array}{l}\text { SD } \\
F(\%)\end{array}$ & $\begin{array}{c}\text { D } \\
F(\%)\end{array}$ & $\begin{array}{c}\mathbf{N} \\
\mathrm{F}(\%)\end{array}$ & $\begin{array}{c}\text { A } \\
F(\%)\end{array}$ & $\begin{array}{c}\text { SA } \\
F(\%)\end{array}$ & Mean \\
\hline 1. & $\begin{array}{l}\text { Teacher always gives group work or } \\
\text { group assignments. }\end{array}$ & $1(2)$ & $1(2)$ & $18(36)$ & $\begin{array}{l}22 \\
(44)\end{array}$ & $8(16)$ & 3.7 \\
\hline 2. & $\begin{array}{l}\text { Teacher always makes small groups in } \\
\text { classroom teaching and for outside } \\
\text { class works. }\end{array}$ & $1(2)$ & $1(2)$ & $17(34)$ & $\begin{array}{l}24 \\
(48)\end{array}$ & $7(14)$ & 3.7 \\
\hline 3. & $\begin{array}{l}\text { From group work, students has a } \\
\text { chance to share ideas with others. }\end{array}$ & $1(2)$ & $1(2)$ & $17(34)$ & $\begin{array}{l}21 \\
(42)\end{array}$ & $10(20)$ & 3.76 \\
\hline & $\sum f$ & 3 & 3 & 52 & 67 & 25 & $\mathrm{~T}: 150$ \\
\hline & $\sum \%$ & 2 & 2 & 34.67 & 44.67 & 16.67 & T: 100 \\
\hline
\end{tabular}

\section{Students' Preference of Using Group Work}

Table 4 shows that $38 \%$ of the students strongly agreed and agreed that they prefer to learn using group work method rather than individual. A higher percentage $(44.67 \%)$ of them was neutral, and $12 \%$ of them disagreed and strongly disagreed. This indicates that although some of them liked group work technique, the majority of the students preferred to have a combination of individual and group work learning.

Table 4. Preference in Using Group Work

\begin{tabular}{|c|c|c|c|c|c|c|c|}
\hline NO. & Statements & $\begin{array}{r}\text { SD } \\
F(\%)\end{array}$ & $\begin{array}{r}\text { D } \\
F(\%)\end{array}$ & $\begin{array}{r}\mathbf{N} \\
\mathrm{F}(\%)\end{array}$ & $\begin{array}{c}\text { A } \\
F(\%)\end{array}$ & $\begin{array}{r}\text { SA } \\
F(\%)\end{array}$ & Mean \\
\hline 1. & $\begin{array}{l}\text { I prefer group work than other types of } \\
\text { learning strategies. }\end{array}$ & $0(0)$ & $2(4)$ & $23(46)$ & $\begin{array}{l}17 \\
(34)\end{array}$ & $8(16)$ & 3.64 \\
\hline 2. & $\begin{array}{l}\text { I prefer working in a group than } \\
\text { working individually beacuse of a } \\
\text { higher grade. }\end{array}$ & $0(0)$ & $6(12)$ & $24(48)$ & $\begin{array}{l}13 \\
(26)\end{array}$ & $7(14)$ & 3.42 \\
\hline 3. & $\begin{array}{l}\text { I prefer doing group assignments than } \\
\text { individual assignments. }\end{array}$ & $4(8)$ & $6(12)$ & $20(40)$ & $\begin{array}{l}19 \\
(18)\end{array}$ & $3(6)$ & 3.34 \\
\hline & $\sum f$ & 4 & 14 & 67 & 49 & 18 & $\mathrm{~T}: 150$ \\
\hline & $\sum \%$ & 2.67 & 9.33 & 44.67 & 26 & 12 & T: 94.67 \\
\hline
\end{tabular}

\section{Factors Hindering Group Work}

As seen in Table 5, 17.2\% of the students agreed and strongly agreed that they met various hindering factors while learning in groups. Meanwhile, $23.2 \%$ of the students was neutral, and $59.6 \%$ of the students disagreed and strongly disagreed about it. For them, seeing from the mean score, some members' unwillingness to participate while working in group $(M=2.74)$ was most significant hindrances. What came next is that some members got good grade without doing work (2.66) and when group members did not share works equally (2.44). 
Table 5. Factors Hindering Group Work

\begin{tabular}{|c|c|c|c|c|c|c|c|}
\hline NO. & Statements & $\begin{array}{r}\text { SD } \\
F(\%)\end{array}$ & $\begin{array}{r}\text { D } \\
F(\%)\end{array}$ & $\begin{array}{r}\mathbf{N} \\
\mathrm{F}(\%)\end{array}$ & $\begin{array}{c}\mathbf{A} \\
\mathrm{F}(\%)\end{array}$ & $\begin{array}{r}\text { SA } \\
\mathrm{F}(\%)\end{array}$ & Mean \\
\hline 1. & Some members do not participate. & $6(12)$ & $16(32)$ & $16(32)$ & $9(18)$ & $3(6)$ & 2.74 \\
\hline 2. & $\begin{array}{l}\text { The task can be completed even if all } \\
\text { members do not contribute. }\end{array}$ & $10(20)$ & $22(44)$ & $12(24)$ & $4(8)$ & $2(4)$ & 2.32 \\
\hline 3. & $\begin{array}{l}\text { Group members do not share works } \\
\text { equally. }\end{array}$ & $6(12)$ & $26(52)$ & $11(22)$ & $4(8)$ & $3(6)$ & 2.44 \\
\hline 4. & $\begin{array}{l}\text { Some members get a good grade } \\
\text { without doing work. }\end{array}$ & $7(14)$ & $18(36)$ & $13(26)$ & $9(18)$ & $3(6)$ & 2.66 \\
\hline 5. & $\begin{array}{l}\text { The group assignment is done by one } \\
\text { student. }\end{array}$ & $17(34)$ & $21(42)$ & $6(12)$ & $3(6)$ & $3(6)$ & 2.08 \\
\hline & $\sum f$ & 46 & 103 & 58 & 29 & 14 & $\mathrm{~T}: 250$ \\
\hline & $\sum \%$ & 18.4 & 41.2 & 23.2 & 11.6 & 5.6 & $\mathrm{~T}: 100$ \\
\hline
\end{tabular}

\section{DISCUSSION}

The findings concerning the advantages of using group work indicate that most students agreed that group work gave some advantages to their learning attitudes. They believed group work advantageous because it helped them solve problem collaboratively, taught them to take responsibility and to negotiate with peers. This confirms Ibnian's (2012) study result showing that group work technique affected students' positive attitudes development.

Findings concerning group work effectiveness indicate that the majority of the students believed group work is an effective learning technique. They viewed group work was most effective to make task completion easier and to shorten the time for handling assignment. These findings are different from Sormunen, Tanni, Alamettälä, and Heinström's (2014) findings showing that the motivation behind the group work was related to quality issues and shared responsibility.

The data on students' perception on teachers' implementation of group work in teaching indicated that most of the students agreed that their teacher always using group work methods in English class. It also showed they believed that group work provided them a chance to share ideas with their peers. This approves Wahyuningsih's (2018) findings revealing that the implementation of group work was able to increase the students' feeling of competence, feeling to be respected, feeling to be loved, feeling to have a chance for success, and feeling of confidence.

The findings also revealed that the students preferred using a combination of individual and group work technique in learning. This finding disapproves, Eric, Shaw, and Duffy's (2007) findings revealing that the students' preference for group work was negative. These contradictory findings revealed more studies are needed to explain this phenomenon.

The findings concerning students' perception on factors hindering group work indicate they encountered no serious hindrances in learning using group work. Some students viewed certain members' unwillingness to participate as a problem, but the number of students who strongly agreed and agreed to this was only $24 \%$. The next significant problem that might hinder learning in group work was the possibility that some students got good grade without doing work. The number of students who strongly agreed and agreed to this was even smaller (12\%). This result was in line with Kondo's (2010), findings showing that group work was better to use in class especially for less-skilled 
students. When they were assigned to work individually, they would find it difficult to complete the task.

Overall, the participants' holistic responses to the whole items of the questionnaire showed that the total 'strongly disagree' responses was $5.11 \%$; 'disagree' was $12,7 \%$; 'neutral', 31.1\%; 'agree', 36.55\%; and 'strongly agree', $13.78 \%$. Thus, it can be concluded that the students' perception of using group work in English classes is positive. It can be seen in Figure 1.

\section{Conclusion}

The results and discussion revealed that the students of SMA 17 Agustus 1945 Jakarta always used group work activities in and outside of the classrooms. The technique helped them develop their readiness to take responsibility, increase their confidence to shares ideas with all members of the group, complete the tasks, and nurture their ability to respect others. Despite these advantages, the students preferred a combination of group work and individual learning in their English classes. Thus, group work brings a positive impact on students learning habits and attitudes personally and in a group.

Based on the findings and discussion, it is recommended for teachers to make the students learn comfortably by choosing the best method, strategies, and techniques that increase their interest while implementing group works in the classroom.

\section{REFERENCES}

Albaqshi, J. (2016, September). Prominent Factors Affecting Group Work Efficiency For EFL Learners. International Journal of English Language Teaching, IV, 67-75.

Chiriac, E. H. (2014, June 5). Frontiers in Psychology. Group Work as an Incentive for Learning - Students' Experiences of Group Work.

Daba, T. M., Ejersa, S. J., \& Aliyi, S. (2017). Student perception on group work and group assignments in classroom teaching: The case of Bule Hora university second year biology students, South Ethiopia: An action research. Academic Journals.

Dhawan, N. (2015). Objective Chemistry For Medical College Entrance, 2/e. Dalam P. D., \& V. Dhawan, Social Work for UGC-NET (hal. 180). New Delhi: McGraw-Hill Education.

Ellis, D., \& Holmes, T. (2017). Implementing Group Work in the Classroom. Retrieved from Centre for Teaching Excellence: https://uwaterloo.ca/centre-for-teachingexcellence/teaching-resources/teaching-tips/alternatives-lecturing/groupwork/implementing-group-work-classroom

Ibnian, S. S. (2012, February). Group Work and Attitudes of Non-English Major Students towards Leaning EFL. International Journal of Humanities and Social Science.

Kondo, A. (2010). Students' Perception of Group Work in EFL Class. Japan: Nara National College of Technology.

Kwon, C. (2014). Student Perspectives on Group Work and Use of L1: Academic Writing in a University EFL Course in Thailand. Second Language Studies, 33(1), 85-124

Meng, F. (2009). Encourage Learners in the Large Class to Speak English in Group Work. CCSE English Language Teaching.

Natalia, H. S. (2018). Students' Perception of The Use of Advice Board Game on Students' Speaking Development at SMK YADIKA 2 Jakarta. Jakarta: Universitas Kristen Indonesia. 
Ning, H. (2013). The Impact of Cooperative Learning on English as a Foreign Language Tertiary Learners' Social Skills. Social Behavior and Personality An International Journal, 557-568.

Pardede, P. (2019). Integrated Skills Approach in EFL Classrooms: A Literature Review. In: PROCEEDING English Education Department Collegiate Forum (EED CF) 2015-2018. Jakarta: UKI Press, 147-159

Pardede, P. (2020). Integrating the 4Cs into EFL Integrated Skills Learning. JET (Journal of English Teaching), 6(1), 71-85.

Phitaloka, T. D. (2015). Students' Opinion on The Use of Group Work in Interpersonal Speaking Class: A Study at The English Language Education Program of Satya Wacana Christian University. Retrieved from https://repository.uksw.edu/bitstream/123456789/10160/2/T1_112010076_Full\%2 Otext.pdf

Risharyani. (2010). Technique in Teaching Reading to The Second Year Student of SMA Muhammadiyah 1 Surakarta. Surakarta: Universitas Muhammadiyah Surakarta.

Rochwati, T. (2007). Improving Students' Ability in Writing Descriptive Text Through Group Work at The First Year of SMA N 8 Surakarta. Surakarta: Universitas Muhammadiyah Surakarta.

Stark, E. M., Shaw, J. D., \& Duffy, M. K. (2007). Preference for Group Work,Winning Orientation, and Social Loafing Behavior in Groups. Group \& Organization Management.

Sormunen, E., Tanni, M., Alamettälä, T., \& Heinström, J. (2014). Students' Group Work Strategies in Source-based Writing Assignments. Journal of the American Society for Information Science and Technology.

Taqi, H. A., \& Al-Nouh, N. A. (2014). Effect of Group Work on EFL Students' Attitudes and Learning in Higher Education.

Tynjala, P. (2012). Writing as a Learning Tool. Springer Science \& Business Media.

Wahyuningsih, S. K. (2018). Group Work to Improve Classroom Interaction and Students' Self-esteem of STAIN GPA. Research and Innovation in Language Learning.

Yanse, S. (2016). Students' Perceptions on The Use of Group Discussion and Their Engagement in The Speaking Sessions of CLS I. Yogyakarta: Sanata Dharma University. 